\title{
Pemberian Makanan Pendamping ASI (MPASI) Sesuai Dengan Usia Bayi Di Desa Bawang Kecamatan Pesantren Kota Kediri
}

\author{
Elin Soyanita1, Dian Kumalasari² \\ ${ }^{1,2}$ Institut Ilmu Kesehatan Bhakti Wiyata Kediri, Indonesia \\ 'elin.soyanita@iik.ac.id, ${ }^{2}$ diankyumalasari.88@gmail.com
}

\begin{tabular}{l}
\hline Informasi artikel \\
\hline Sejarah artikel: \\
Diterima:08-11-2019 \\
Publikasi:28-11-2019
\end{tabular}

\begin{abstract}
ABSTRAK
Masa pertumbuhan bayi dan balita merupakan masa yang paling berharga. Salah satu masa terpenting yaitu disaat bayi mulai makan makanan pendamping ASI. Jika pemberian makanan pendamping ASI tidak sesuai bisa menyebabkan bayi mengalami gizi kurang dan bisa menjadi gizi buruk jika tidak mendapatkan penanganan dengan baik. Tujuan penelitian untuk mengetahui faktor yang berhubungan dengan pemberian makanan pendamping ASI sesuai dengan usia bayi. Jenis penelitian analitik dengan pendekatan cross sectional, subjek penelitian adalah ibu yang memiliki anak usia lebih dari 6 bulan yang datang ke posyandu desa bawang kecamatan pesantren kabupaten kediri sebanyak 34 orang. Analisis statistik dengan uji Chi Square. Hasil penelitian menunjukkan pemberian makanan pendamping ASI usia $\geq 6$ bulan sebanyak 64,7\%, responden mendapatkan informasi tentang makanan pendamping ASI sebanyak 64,7\%, Responden memiliki pengetahuan baik sebanyak 70,6 \% dan mempunyai sikap positif sebanyak 67,6 \%. Hasil analisis statistik menunjukkan tidak ada hubungan sumber informasi dengan pemberian makanan pendamping ASI sesuai usia, ada hubungan pengetahuan dan sikap dengan pemberian makanan pendamping ASI sesuai dengan usia. Petugas kesehatan dapat lebih meningkatkan lagi dalam pemberian pendidikan kesehatan atau penyuluhan tentang makanan pendamping ASI.
\end{abstract}

Kata kunci:

Pengetahuan,

Sikap,

Sumber Informasi, MPASI
Key word:

Knlowledges, Attitude, sources of information, MPASI

\begin{abstract}
The growth period of infants and toddlers is the most valuable period. One of the most important times is when the baby starts eating complementary foods. If the provision of complementary feeding is inappropriate, it can cause the baby to experience malnutrition and can become malnourished if not handled properly. The purpose of the study was to determine factors associated with complementary feeding according to the age of the baby. This type of analytic research with cross sectional approach, research subjects are mothers who have children aged more than 6 months who come to the posyandu bawang village, pesantren district, Kediri district as many as 34 people. Statistical analysis with Chi Square test. The results showed that 64.7\% complementary feeding of ASI aged 6 months, respondents received information about 64.7\% complementary food, Respondents had good knowledge of $70.6 \%$ and had a positive attitude of $67.6 \%$. The results of statistical analysis show that there is no relationship between sources of information with complementary feeding according to age, there is a relationship between knowledge and attitude with supplementary feeding according to age. Health workers can further enhance health education or counseling about complementary feeding.
\end{abstract}

\section{PENDAHULUAN}

Masa pertumbuhan bayi dan balita merupakan masa yang paling berharga. Dalam setiap langkah-langkah dan perkembangannya orang tua mempunyai keinginan untuk memberikan yang terbaik. Salah satu masa terpenting yaitu disaat bayi mulai makan makanan pendamping ASI.
Pada dasarnya pemberian makanan pendamping ASI dimulai pada usia lebih dari 6 bulan. Pada saat bayi usia 0 - 5 bulan seluruh makanan bayi diperoleh $100 \%$ dari makanan cair (ASI / susu formula) dan pada saat memasuki umur 6 bulan terdapat kesenjangan energi yang kurang terpenuhi hanya dengan memberikan ASI atau susu 
formula, oleh sebab itu membutuhkan makanan pendamping ASI. Menurut WHO alasan pemberian makanan pendamping asi pada usia 6 bulan karena bayi memerlukan tambahan energi dan zat gizi makanan lebih banyak terutama zat besi dan hal ini tidak bisa terpenuhi hanya dengan memberikan ASI, bayi sudah mampu duduk dan menopang lehernya sehingga mengurangi resiko tersedak, saluran pencernaan sudah lebih kuat, ada kesenjangan kebutuhan energi yang harus diisi oleh makanan padat dan refleks penolakan terhadap sendok sudah lebih rendah. Menurut WHO Kebutuhan energi usia 6 - 8 bulan adalah kurang lebih 700 kkal dan energi yang didapat dari ASI kurang lebih 450 kkal dan kekurangannya dapat dipenuhi dari pemberian makanan tambahan (Dian Prima, 2015)

Semakin bertambah usia bayi semakin besar kebutuhan makanan pendamping asi yang harus dipenuhi. Dalam memberikan makanan pendamping ASI yang harus diperhatikan adalah jumlah yang diberikan harus sesuai dalam hal ini kuantitas dan kualitasnya serta bentuk dari makanan pendamping ASI. Jika makanan pendamping ASI yang diberikan tidak sesuai bisa menyebabkan bayi mengalami gizi kurang dan bisa menjadi gizi buruk jika tidak mendapatkan penanganan dengan baik (Dian Prima, 2015).

Berdasarkan hasil riset Kesehatan Dasar (Riskesdas) Kementerian Kesehatan 2018 menunnjukkan bahwa bayi usia di bawah 5 tahun yang mengalami masalah gizi sebesar 17,7 \% yang terdiri darai balita dengan gizi buruk sejumlah 3,9\% dan gizi kurang sejumlah 13,8\%, sedangkan dalam Rencana Pembangunan Jangka Menengah Nasional (RPJMN) 2019 ditargetkan bayi yang mengalami masalah gizi turun menjadi 17\%. Dari 34 provinsi di Indonesia, Jawatimur merupakan provinsi yang memunyai jumlah balita yang mengalami masalah gizi kurang cukup besar yaitu sebanyak 12,6\% pada Tahun 2017 dan mengalami peningkatan pada Tahun 2018 menjadi $13,4 \%$. Di kota Kediri terdapat beberapa kecamatan yang salah satunya adalah kecamatan pesantren, dimana di daerah tersebut masih terdapat balitsa dengan gizi buruk sejumlah 14 balita pada tahun 2017.

Upaya untuk mengatasi gizi kurang pada balita yaitu dengan program Germas (Gerakan Masyarakat Hidup Sehat) serta adanya sinergi program kementrian dan lembaga yang programnya terdiri dari peningkatan derajat kesehatan ibu dan anak, sosialisasi dan edukasi untuk pemberian ASI secara ekslusif selama enam bulan dan dilanjutkan sampai usia dua tahun dengan pemberian makanan pendamping ASI. Menurut penelitian sebelumnya faktor yang mempengaruhi Dalam pemberian makanan pendamping ASI adalah pengetahua dan pekerjaan (dwi Wahyu Windarti dan Laily Nikmah), dukungan keluarga, pendidikan dan tradisi (Rahmalia Afriyan, Shintya Halisa dan Hetty Rolina), usia pertama pemberian MPASI, frekuensi pemberian, jenis makanan dan jumlah dalam pemberian makanan pendamping ASI (Endang Retnowati).

Berdasarkan latar belakang tersebut maka rumusan masalahnya adalah apakah faktor - faktor yang berhubungan dengan pemberian makanan pendamping ASI sesuai dengan usia bayi. Tujuan penelitian ini adalah untuk mengetahui faktor yang berhubungan dengan pemberian makanan pendamping ASI sesuai dengan usia bayi.

\section{METODE PENELITIAN}

Penelitian ini merupakan penelitian analitik dengan menggunakan pendekatan cross sectional, subjek yang diteliti adalah ibu yang mempunyai anak usia lebih dari 6 bulan yang datang ke posyandu desa bawang kecamatan pesantren kabupaten kediri sebanyak 34 orang. Teknik sampel yang digunakan adalah total sampling. Varibel bebasnya adalah sumber informasi, pengetahuan dan sikap sedangakan variabel terikatnya adalah pemberian makanan pendamping ASI. Data yang digunakan dalam penelitian ini adalah data primer yaitu data yang diperoleh dengan membagikan instrumen penelitian yaitu berupa kuesioner. Data penelitian yang diolah dan dilakukan analisis dengan uji Khi kuadrat (Chi Square).

HASIL DAN PEMBAHASAN

1. Karakteristik Responden

\begin{tabular}{ccc}
\hline Umur & Jumlah & Presentase \\
\hline $26->35$ Tahun & 21 & 61,8 \\
$<20-25$ Tahun & 13 & 38,2 \\
\hline Pendidikan & Jumlah & Presentase \\
\hline Tinggi & 25 & 73,5 \\
\hline Rendah & 9 & 26,5 \\
\hline Pekerjaan & Jumlah & Presentase \\
\hline Bekerja & 12 & 35,3 \\
\hline $\begin{array}{c}\text { Tidak bekerja } \\
\text { (IRT) }\end{array}$ & 22 & 64,7 \\
\hline
\end{tabular}


bivariat diperoleh $\mathrm{p}$ value 0,001 yang artinya ada hubungan antara pengetahuan dengan pemberian makanan pendamping ASI sesuai dengan usia.

Pengetahuan adalah hasil tahu dari seseorang terhadap suatu objek yang didapatkan setelah orang mengadakan penginderaan terhadap objek tertentu. Penginderaan terhadap objek terjadi mealui panca indra manusia (penglihatan, pendengaran, penciuman, rasa dan raba) dengan sendiri dan sebagian besar pengetahuan manusia didapatkan melalui mata dan telinga. Beberapa faktor yang mempengaruhi Pengetahuan seseorang, salah satunya adalah faktor pendidikan terutama pendidikan formal. Semakin tinggi pendidikan seseorang maka pengetahuan seseorang akan semakin luas. Pengetahuan seseorang tidak hanya dapat diperoleh melalui pendidikan formal tetapi juga dari pendidikan non formal.

Sejalan dengan hasil penelitian eko Heryanto tentang faktor - faktor yang berhubungan dnegan pemberian makanan pendamping ASI dini yaitu terdapat hubungan yang bermakna antara pengetahuan responden dengan pemberian MPASI dini dimana responden yang mempunyai pengetahuan kurang bayinya diberi MPASI dini sejumlah 16 orang (64\%) dan responden yang mempunyai pengetahuan baik dan melakukan pemberian MPASI dini sebanyak 7 orang (26,9\%), jadi pengetahuan ibu dengan pemberian MPASI terdapat hubungan yang erat.

Hasil penelitian menunjukkan ada hubungan antara pengetahuan dengan pemberian makanan pendamping ASI, dimana ibu dengan pengetahuan baik cenderung memberikan makanan pendamping ASI sesuai usia daripada dengan ibu yang memiliki pengetahuan kurang. Ibu dengan pengetahuan baik lebih memahami bahwa makanan pendamping ASI diberikan pada usia bayi 6 bulan karena sebelum usia 6 bulan bayi hanya memerlukan ASI saja karean pencernaan bayi hanya mampu mencerna ASI. Semakin baik pengetahuan seseorang maka akan melakukan pemberian makanan pendamping ASI sesuai dengan usia.

Hubungan sikap dengan Pemberian Makanan Pendamping ASI

Terdapat hubungan antara sikap dengan pemberian makanan pendamping ASI dengan $\mathrm{p}$ value 0,0013
Sikap merupakan persepsi, kepercayaan yang dimiliki individu mengenai suatu objek yang dapat menimbulkann ide, gagasan tentang objek yang dilihat. Beberapa faktor yang mempengaruhi Sikap yaitu pengetahuan, pengalaman pribadi, pengaruh orang lain yang dianggap penting, pengaruh kebudayaan, media massa, dan pengaruuh faktor emosional. Sikap dapat berpengaruh terhadap perilaku seseorang karena perilaku kesehatan seseorang terbentuk karena pengaruh beberapa faktor yaitu pengetahuan, sikap dan kepercayaan. Dengan seseorang mempunyai sikap yang positif maka akan mempunyai perilaku yang positif.

Sejalan dengan penelitian Dian Periwiri BR Bangun tentang hubungan pengetahuan dan sikap ibu terhadap pemberian makanan pendamping asi (mp-asi) pada bayi dan baduta (6- 24 bulan) di puskesmas kabanjahe kabupaten karo tahun 2016 dengan hasil penelitian ada pengaruh sikap responden terhadap pemberian makanan pendamping ASI (MP-ASI) pada bayi dan baduta (6- 24 bulan) di Puskesmas Kabanjahe Kabupaten Karo.

KESIMPULAN

Dari hasil penelitian menunjukkan bahwa tidak ada hubungan antara sumber informasi $(\mathrm{P}$ value $>0,05)$ dengan pemberian makanan pendamping ASI sesuai usia, terdapat hubungan antara pengetahu (Pvalue $<0,05$ ) dan sikap (Pvalue $<0,05)$ dengan pemberian makanan pendamping ASI sesuai usia. Diharapakan petugas kesehatan lebih meningkatkan lagi dalam memberikan pendidikan kesehatan atau penyuluhan tentang pemberian makanan pendamping ASI.

\section{DAFTAR PUSTAKA}

Buku Teori. 2018. Sumber Informasi (https://bukuteori.com/2018/09/22/pe ngertian-sumber-informasi/)

Catur Saptaning Wilujeng. 2017. Faktor yang Mempengaruhi Pemberian Makanan Pendamping ASI terhadap Berat Anak Usia 6 - 24 Bulan di Puskesmas Cluwak Kabupaten Pati (https:// majalahfk:ub.ac.id $>$ index.php $>$ mkfkub $>$ article $>$ download)

Depkes RI. 2018. Hasil Utama Riskesdas 2017. (online). diunduh dari www.depkes.go.id

Depkes RI. 2018. Profil Kesehatan Provinsi Jawa Timur 2017. (online). diunduh dari www.depkes.go.id 
Dinkes Kota Kediri. 2017.Profil Kesehatan Kota Kediri. (online). diunduh dari www.depkes.go.id resouces/download/profil/PROFIL-KABKOTA-2017/3571-Jatim-kota-kediri2017.pdf

Dian Prima Zahriah dan Yudith Mangiri.2015. MPASI Perdana Cihuy: Pedoman Makanan Pendamping ASI usia 6-12 Bulan. Asha book: Jakarta

Dian Periwiri BR Bangun. 2016. Hubungan Pengetahuan Dan Sikap Ibu Terhadap Pemberian Makanan Pendamping Asi (Mp-Asi) Pada Bayi Dan Baduta (6- 24 Bulan) Di Puskesmas Kabanjahe Kabupaten Karo Tahun 2016 (http://repository.usu.ac.id/bitstream/h andle/123456789/63161/Cover.pdf?seq uence $=7 \&$ isAllowed $=y$ )

Dwi Wahyu Windarti dan Laily Nikmah. 2012. Faktor - Faktor yang mempengaruhi pemberian MPASI dini pada usia 7 - 24 bulan di di wilayah kerja PKM Nanggulan Kulonprogo Tahun 2012 (digilib.unisajogja.ac.id/3715)

Eko Heryanto. 2017. Faktor - Faktor yang Berhubungan dengan Pemberian Makanan Pendamping ASI Dini. (https://aisyah.journal press.id/index.php/kika/article/view/E H)

Endang Retnowati. 2014. Faktor - Faktor yang Mempengaruhi Ketepatan Waktu Pemberian Makanan Pendamping ASI Pada Bayi 6 - 11 Bulan di Wilayah Kerja Puskesmas Sewon I Bantul Tahun 2014 ( digilib.unisayogya.ac.id/961/1/NASKAH PUBLIKASI.pdf)

Indriyani Astuti. 2017. Pemerintah Serius Menangani Gizi Buruk. (http://mediaindonesia.com/read/detail /117844-pemerintah-serius-menanganigizi-buruk)

Notoatmodjo, Soekidjo. 2010. Ilmu Perilaku Kesehatan. Jakarta : PT. Rineka Cipta

Notoatmodjo, Soekidjo. 2010. Metodologi Penelitian Kesehatan. Jakarta : PT. Rineka Cipta.

Rahmalia Afriyan, Shintya Halisa dan Hetty Rolina. 2016. Faktor - faktor yang berhubungan dengan pemberian MP-ASI pada bayi usia 0-6 bulan di BPM Nurtilla Palembang (http://ejurnal.pltekkestjk.ac.id $>$ index.php $>$ article $>$ view)

Yonatan Kristanto. 2013. Faktor yang Mempengaruhi Perilaku Ibu dalam Pemberian Makanan Pendamping ASI pada Bayi umur 6 - 36 Bulan (Puslit2.petra.ac.id $>$ ejournal.index.php;s tikes $>$ article $>$ download) 